\title{
Relation between Presynaptic and Postsynaptic Dopaminergic Functions Measured by Positron Emission Tomography: Implication of Dopaminergic Tone
}

\author{
Hiroshi Ito, Fumitoshi Kodaka, Hidehiko Takahashi, Harumasa Takano, Ryosuke Arakawa, Hitoshi Shimada, \\ and Tetsuya Suhara \\ Clinical Neuroimaging Team, Molecular Neuroimaging Group, Molecular Imaging Center, National Institute of Radiological Sciences, Chiba 263-8555, Japan
}

\begin{abstract}
Both presynaptic and postsynaptic dopaminergic functions can be estimated by positron emission tomography (PET). While both presynaptic and postsynaptic dopaminergic functions would be regulated by corresponding genes and related to personality traits, the relation between presynaptic and postsynaptic functions in terms of interindividual variation has hardly been investigated. In the present study, both striatal dopamine $\mathrm{D}_{2}$ receptor binding and endogenous dopamine synthesis rate were measured in the same healthy subjects using PET with $\left[{ }^{11} \mathrm{C}\right]$ raclopride and $\mathrm{L}-\left[\beta{ }^{11} \mathrm{C}\right] \mathrm{DOPA}$, respectively, and these two parameters were compared. Two PET studies with $\left[{ }^{11} \mathrm{C}\right]$ raclopride and $\mathrm{L}-\left[\beta^{-11} \mathrm{C}\right] \mathrm{DOPA}$ were performed sequentially at rest condition on 14 healthy men. For $\left[{ }^{11} \mathrm{C}\right]$ raclopride PET, the binding potential was calculated by the reference tissue model method. For $\mathrm{L}-\left[\beta-{ }^{11} \mathrm{C}\right] \mathrm{DOPA}$ PET, the endogenous dopamine synthesis rate was estimated by graphical analysis. A significant negative correlation was observed between the binding potential of dopamine $\mathrm{D}_{2}$ receptors and endogenous dopamine synthesis rate $(r=-0.66, p<0.05)$. Although the interindividual variation of binding potential of $\left[{ }^{11} \mathrm{C}\right]$ raclopride would be due to both the interindividual difference in the receptor density and that in the concentration of endogenous dopamine in the synaptic cleft, the negative correlation between parameters for both presynaptic and postsynaptic functions might indicate a compensative relation between the two functions.
\end{abstract}

\section{Introduction}

The central dopaminergic system is of interest in the pathophysiology of schizophrenia and other neuropsychiatric disorders. Both presynaptic and postsynaptic dopaminergic functions can be estimated by positron emission tomography (PET) using several radiotracers. The binding of dopamine receptors representing postsynaptic functions in the striatum can be measured for each of $\mathrm{D}_{1}$ and $\mathrm{D}_{2}$ subtypes using $\left[{ }^{11} \mathrm{C}\right] \mathrm{SCH} 23390$ (Halldin et al., 1986; Farde et al., 1987) and $\left[{ }^{11} \mathrm{C}\right]$ raclopride (Farde et al., 1985; Köhler et al., 1985; Ito et al., 1998), respectively. The relative activity of cerebral aromatic L-amino acid decarboxylase (AADC) representing endogenous dopamine synthesis rate measured by 6- $\left[{ }^{18} \mathrm{~F}\right]$ fluoro-L-DOPA (Gjedde, 1988; Gjedde et al., 1991; Huang

Received Nov. 17, 2010; revised April 11, 2011; accepted April 12, 2011.

Author contributions: H.I., H. Takano, R.A., and T.S. designed research; H.I., F.K., H. Takahashi, H. Takano, R.A., and H.S. performed research; F.K. contributed unpublished reagents/analytic tools; H.I. and F.K. analyzed data; H.I. and T.S. wrote the paper.

This study was supported in part by a Grant-in-Aid for Molecular Imaging Program from the Ministry of Education, Culture, Sports, Science, and Technology, Japanese Government, a Grant-in-Aid for Scientific Research (C) (No. 21591587) from the Japan Society for the Promotion of Science, and a grant from the National Institute of Radiological Sciences. We thank Katsuyuki Tanimoto and Takahiro Shiraishi for their assistance in performing the PET experiments at the National Institute of Radiological Sciences. We also thank Yoshiko Fukushima, Kazuko Suzuki, and Idumi Izumida of the National Institute of Radiological Sciences for their help as clinical research coordinators.

The authors declare no competing financial interests.

Correspondence should be addressed to Dr. Hiroshi Ito, Clinical Neuroimaging Team, Molecular Neuroimaging Group, Molecular Imaging Center, National Institute of Radiological Sciences, 4-9-1 Anagawa, Inage-ku, Chiba 263-8555, Japan. E-mail: hito@nirs.go.jp.

DOI:10.1523/JNEUROSCI.6024-10.2011

Copyright $\odot 2011$ the authors $\quad 0270-6474 / 11 / 317886-05 \$ 15.00 / 0$ et al., 1991) and $\mathrm{L}-\left[\beta_{-}{ }^{11} \mathrm{C}\right] \mathrm{DOPA}$ (Hartvig et al., 1991; Tedroff et al., 1992) can indicate the presynaptic dopaminergic function. Using PET, interindividual variations in both presynaptic and postsynaptic dopaminergic functions in the striatum of normal living human brain were observed (Ito et al., 2008).

It has been reported that the dopamine $\mathrm{D}_{2}$ receptor density was related to polymorphisms in the dopamine $\mathrm{D}_{2}$ receptor gene in humans (Jönsson et al., 1999). Genotypes of human monoaminesynthesizing enzymes, e.g., tyrosine hydroxylase (TH) and AADC, were also determined (Nagatsu, 1991), and TH genotypes were reported to participate in the regulation of monoamine turnover in the CNS (Jönsson et al., 1996). It has been reported that dopamine $\mathrm{D}_{2}$ receptor binding and the endogenous dopamine synthesis rate measured by PET were correlated with personality traits (Farde et al., 1997; Breier et al., 1998; Laakso et al., 2003).

While both presynaptic and postsynaptic dopaminergic functions would be regulated by corresponding genes and related to personality traits, the relation between presynaptic and postsynaptic functions in interindividual variation has hardly been investigated. In the present study, both striatal dopamine $\mathrm{D}_{2}$ receptor binding and endogenous dopamine synthesis rate were measured in the same healthy subjects using PET with $\left[{ }^{11} \mathrm{C}\right]$ raclopride and $\mathrm{L}-\left[\beta_{-}{ }^{11} \mathrm{C}\right]$ DOPA, respectively, and these two parameters were compared.

\section{Materials and Methods}

Subjects. The study was approved by the Ethics and Radiation Safety Committees of the National Institute of Radiological Sciences, Chiba, Japan. Fourteen healthy men [20-29 years of age, $23.8 \pm 2.9$ years 
(mean $\pm \mathrm{SD})]$ were recruited and written informed consent was obtained. The subjects were free of somatic, neurological, or psychiatric disorders on the basis of their medical history and magnetic resonance (MR) imaging of the brain. They had no history of current or previous drug abuse.

PET procedures. All PET studies were performed with a Siemens ECAT Exact HR + system, which provides 63 sections with an axial field of view of $15.5 \mathrm{~cm}$ (Brix et al., 1997). The intrinsic spatial resolution was $4.3 \mathrm{~mm}$ in-plane and $4.2 \mathrm{~mm}$ full-width at half-maximum (FWHM) axially. With a Hanning filter (cutoff frequency: 0.4 cycle/pixel), the reconstructed in-plane resolution was $7.5 \mathrm{~mm}$ FWHM. Data were acquired in three-dimensional mode. Scatter was corrected (Watson et al., 1996). A 10 min transmission scan using a ${ }^{68} \mathrm{Ge}-{ }^{68} \mathrm{Ga}$ line source was performed for correction of attenuation. A head fixation device with thermoplastic attachments for individual fit minimized head movement during PET measurements. Two PET studies with $\left[{ }^{11} \mathrm{C}\right]$ raclopride and $\mathrm{L}-\left[\beta-{ }^{11} \mathrm{C}\right]$ DOPA were performed sequentially at rest condition. After intravenous rapid bolus injection of $\left[{ }^{11} \mathrm{C}\right]$ raclopride, dynamic PET scanning was performed for $60 \mathrm{~min}$. After $1 \mathrm{~h}$ from the end of $\left[{ }^{11} \mathrm{C}\right]$ raclopride PET measurement, dynamic PET scanning was performed for 89 min after intravenous rapid bolus injection of $\mathrm{L}-\left[\beta-{ }^{11} \mathrm{C}\right] \mathrm{DOPA}$. In one subject, the $\mathrm{L}-\left[\beta-{ }^{11} \mathrm{C}\right]$ DOPA PET measurement was performed $5 \mathrm{~d}$ after the $\left[{ }^{11} \mathrm{C}\right] \mathrm{ra}-$ clopride PET measurement. The frame sequence consisted of twelve $20 \mathrm{~s}$ frames, sixteen $1 \mathrm{~min}$ frames, and ten $4 \mathrm{~min}$ frames for $\left[{ }^{11} \mathrm{C}\right]$ raclopride, and seven $1 \mathrm{~min}$ frames, five $2 \mathrm{~min}$ frames, four $3 \mathrm{~min}$ frames, and twelve $5 \mathrm{~min}$ frames for $\mathrm{L}-\left[\beta_{-}{ }^{11} \mathrm{C}\right] \mathrm{DOPA}$. The radioactivity injected was $194-$ $230 \mathrm{MBq}$ and $342-395 \mathrm{MBq}$ for $\left[{ }^{11} \mathrm{C}\right]$ raclopride and $\mathrm{L}-\left[\beta^{-1}{ }^{11} \mathrm{C}\right] \mathrm{DOPA}$, respectively. The specific radioactivity was $168-517 \mathrm{GBq} / \mu \mathrm{mol}$ and $26-88 \mathrm{GBq} / \mu \mathrm{mol}$ for $\left[{ }^{11} \mathrm{C}\right]$ raclopride and $\mathrm{L}-\left[\beta-{ }^{11} \mathrm{C}\right] \mathrm{DOPA}$, respectively. A venous blood sample was taken at the beginning of $L-[\beta-$ $\left.{ }^{11} \mathrm{C}\right]$ DOPA PET scanning for measurement of natural neutral amino acid (NAA) concentration in plasma. NAA concentration was measured by HPLC (L-8500 amino acid analyzer system, Hitachi). The amino acids are phenylalanine, tryptophan, leucine, methionine, isoleucine, tyrosine, histidine, valine, and threonine, which are transported via the same carrier at the blood-brain barrier as L-DOPA (Sugaya et al., 2001). A weighted sum of the NAAs, which was the L-DOPA-corresponding concentration of the nine NAAs for the carrier system, was calculated according to our previous study (Ito et al., 2006).

All MR imaging studies were performed with a 1.5 tesla MR scanner (Philips Medical Systems). Three-dimensional volumetric acquisition of a T1-weighted gradient echo sequence produced a gapless series of thin transverse sections (TE: $9.2 \mathrm{~ms}$; TR: $21 \mathrm{~ms}$; flip angle: $30^{\circ}$; field of view: $256 \mathrm{~mm}$; acquisition matrix: $256 \times 256$; slice thickness: $1 \mathrm{~mm}$ ).

Regions of interest. All MR images were coregistered to the PET images with the statistical parametric mapping (SPM2) system (Friston et al., 1990). Regions of interest (ROIs) were drawn on coregistered MR images and transferred to the PET images. ROIs were defined for the cerebellar cortex, caudate head, putamen, and occipital cortex. Each ROI was drawn in three adjacent sections and data were pooled to obtain the average radioactivity concentration for the whole volume of interest. The radioactivity concentration of the striatum was calculated as the average of values of caudate head and putamen. To obtain regional time-activity curves, regional radioactivity was calculated for each frame, corrected for decay, and plotted versus time. No software correction for head movement during PET measurements was applied to the dynamic PET images.

Calculation of dopamine $\mathrm{D}_{2}$ receptor binding. For PET studies with $\left[{ }^{11} \mathrm{C}\right]$ raclopride, the binding potential $\left(\mathrm{BP}_{\mathrm{ND}}\right)$ was calculated by the reference tissue model method (Lammertsma and Hume, 1996; Lammertsma et al., 1996). With this method, the time-activity curve in the brain region is described by that in the reference region with no specific binding, assuming that both regions have the same level of nondisplaceable radioligand binding:

$$
\begin{array}{r}
C_{i}(t)=R_{I} \cdot C_{r}(t)+\left\{k_{2}-R_{I} \cdot k_{2} /\left(1+\mathrm{BP}_{\mathrm{ND}}\right)\right\} \cdot C_{r}(t) \\
\\
\quad \otimes \exp \left\{-k_{2} \cdot t /\left(1+\mathrm{BP}_{\mathrm{ND}}\right)\right\},
\end{array}
$$

where $C_{i}$ is the radioactivity concentration in a brain region; $C_{r}$ is the radioactivity concentration in the reference region; $R_{I}$ is the ratio of
Table 1. The binding potential $\left(\mathrm{BP}_{\mathrm{ND}}\right)$ of $\left[{ }^{11} \mathrm{C}\right]$ raclopride studies and dopamine synthesis rate $k_{\text {ref }}$ of $\mathrm{L}-\left[\boldsymbol{\beta}^{-11} \mathrm{C}\right] \mathrm{DOPA}$ studies

\begin{tabular}{lccc}
\hline & Caudate head & Putamen & Striatum \\
\hline $\mathrm{BP}_{\mathrm{ND}}$ & $2.66 \pm 0.23$ & $3.40 \pm 0.29$ & $3.15 \pm 0.26$ \\
$k_{\text {ref }}\left(\min ^{-1}\right)$ & $0.0118 \pm 0.0019$ & $0.0135 \pm 0.0016$ & $0.0129 \pm 0.0015$ \\
\hline
\end{tabular}

Values are mean \pm SD

$K_{1} / K_{1}^{\prime}\left(K_{1}\right.$, influx rate constant for the brain region; $K_{1}^{\prime}$, influx rate constant for the reference region); $k_{2}$ is the efflux rate constant for the brain region; and 196 denotes the convolution integral. $\mathrm{BP}_{\mathrm{ND}}$ is defined as $\mathrm{BP}_{\mathrm{ND}}=f_{\mathrm{ND}} B_{\text {avail }} / K_{\mathrm{D}}$, where $B_{\text {avail }}$ is the receptor density available to bind radiotracer in vivo and $K_{\mathrm{D}}$ is the dissociation constant indicating affinity of radiotracer to receptors (Innis et al., 2007). $f_{\mathrm{ND}}$ is the free fraction of radiotracer in the compartment of nondisplaceable binding. In this analysis, three parameters $\left(\mathrm{BP}_{\mathrm{ND}}, R_{I}\right.$, and $\left.k_{2}\right)$ were estimated by nonlinear least-squares curve fitting. The cerebellum was used as reference region.

Calculation of dopamine synthesis rate. The uptake rate constant for $\mathrm{L}-\left[\beta-{ }^{11} \mathrm{C}\right] \mathrm{DOPA}$ indicating the dopamine synthesis rate was estimated using graphical analysis (Patlak and Blasberg, 1985; Gjedde, 1988; Ito et al., 2006), which allows for the calculation of the uptake rate constant $\left(k_{\text {ref }}\right)$ using time-activity data in a reference brain region with no irreversible binding. $k_{\text {ref }}$ values can be estimated by using simple linear leastsquares fitting as follows:

$$
\frac{C_{i}(t)}{C_{i}^{\prime}(t)}=k_{\mathrm{ref}} \cdot \frac{\int_{0}^{t} C_{i}^{\prime}(\tau) d \tau}{C_{i}^{\prime}(\tau)}+F \quad t>t^{\star},
$$

where $C_{i}$ and $C_{i}^{\prime}$ are the total radioactivity concentrations in a brain region with and without irreversible binding, respectively, and $t^{*}$ is the equilibrium time of the compartment for unchanged radiotracer in brain tissue. Plotting $C_{i}(t) / C_{i}^{\prime}(t)$ versus $\int_{0}^{t} C_{i}^{\prime}(\tau) d \tau / C_{i}^{\prime}(t)$, after time $t^{*}$, yields a straight line with the slope $k_{\text {ref }}$ and intercept $F$. In the present study, the occipital cortex was used as a reference region with no irreversible binding, because this region is known to have the lowest dopamine concentration (Brown et al., 1979) and lowest AADC activity (Lloyd and Hornykiewicz, 1972). The equilibrium time $t^{*}$ was set to be $29 \mathrm{~min}$, and data plots of 29-89 min were used for linear least-squares fitting (Ito et al., 2006, 2007).

\section{Results}

The $\mathrm{BP}_{\mathrm{ND}}$ of the $\left[{ }^{11} \mathrm{C}\right]$ raclopride studies and dopamine synthesis rate $k_{\text {ref }}$ of the $\mathrm{L}-\left[\beta^{-11} \mathrm{C}\right] \mathrm{DOPA}$ studies are shown in Table 1 . Weighted sum of the NAAs in plasma was $1262 \pm 186 \mathrm{nmol} / \mathrm{ml}$ (mean $\pm \mathrm{SD}$ ) for $\mathrm{L}-\left[\beta-{ }^{11} \mathrm{C}\right] \mathrm{DOPA}$ studies. No significant correlation was observed between weighted sum of the NAAs and the dopamine synthesis rate $k_{\text {ref }}$ of $\mathrm{L}-\left[\beta-{ }^{11} \mathrm{C}\right]$ DOPA.

Relations between $\mathrm{BP}_{\mathrm{ND}}$ and $k_{\text {ref }}$ in the striatum are shown in Figure 1. A significant negative correlation was observed between $\mathrm{BP}_{\mathrm{ND}}$ and $k_{\mathrm{ref}}\left(y=-0.0038 x+0.025, x: \mathrm{BP}_{\mathrm{ND}}, y: k_{\mathrm{ref}}, r=-0.66\right.$, $p<0.05)$. A trend of negative correlation was observed between $\mathrm{BP}_{\mathrm{ND}}$ and $k_{\mathrm{ref}}$ in the putamen $\left(y=-0.0028 x+0.023, x: \mathrm{BP}_{\mathrm{ND}}, y\right.$ : $\left.k_{\mathrm{ref}}, r=-0.51, p<0.1\right)$. No significant correlation was observed in the caudate head $\left(y=-0.0028 x+0.019, x: \mathrm{BP}_{\mathrm{ND}}, y: k_{\mathrm{ref}}, r=\right.$ $-0.35)$. Typical images of $\mathrm{BP}_{\mathrm{ND}}$ of subjects with low and high $\mathrm{BP} \mathrm{ND}_{\mathrm{ND}}$ and corresponding images indicating dopamine synthesis rate are shown in Figure 2.

\section{Discussion}

To our knowledge, there are only a few reports concerning the relation between striatal dopamine $\mathrm{D}_{2}$ receptor binding and endogenous dopamine synthesis ability in the living human brain, and no significant correlation was observed (Heinz et al., 2005; Kienast et al., 2008). Although the coefficient of variation of 
$\mathrm{BP}_{\mathrm{ND}}$ values for $\left[{ }^{11} \mathrm{C}\right]$ raclopride studies and $k_{\mathrm{ref}}$ values for $\mathrm{L}-[\beta$ ${ }^{11} \mathrm{C}$ ]DOPA studies were relatively small ( $8 \%$ for $\mathrm{BP}_{\mathrm{ND}}$ and $12 \%$ for $k_{\text {ref }}$ in the striatum), a significant negative correlation was observed between the parameters for both presynaptic and postsynaptic functions. One possible reason for this is the competition between $\left[{ }^{11} \mathrm{C}\right]$ raclopride and endogenous dopamine at dopamine $\mathrm{D}_{2}$ receptor sites (Reeves et al., 2007). When the endogenous dopamine synthesis rate measured by PET is either small or large, the concentration of endogenous dopamine in the synaptic cleft must be either low or high, and therefore $\left[{ }^{11} \mathrm{C}\right] \mathrm{ra}$ clopride binding to dopamine $\mathrm{D}_{2}$ receptors might become large or small due to competition with the endogenous dopamine, respectively. Recently, the increases in $\mathrm{L}-\left[\beta-{ }^{11} \mathrm{C}\right] \mathrm{DOPA}$ metabolites, $\left[{ }^{11} \mathrm{C}\right] 3,4$-dihydroxyphenylacetic acid $\left(\left[{ }^{11} \mathrm{C}\right] \mathrm{DOPAC}\right)$ and $\left[{ }^{11} \mathrm{C}\right]$ homovanillic acid $\left(\left[{ }^{11} \mathrm{C}\right] \mathrm{HVA}\right)$ in the extracellular space of the rat striatum after intravenous infusion of $\mathrm{L}_{-}\left[\beta_{-}{ }^{11} \mathrm{C}\right] \mathrm{DOPA}$ was reported using microdialysis, indicating that the endogenous dopamine synthesis rate measured by PET can reflect the concentration of endogenous dopamine in the synaptic cleft (Okada et al., 2011). While interindividual variations of $\mathrm{BP}_{\mathrm{ND}}\left(f_{\mathrm{ND}} B_{\text {avail }} /\right.$ $K_{\mathrm{D}}$ ) of $\left[{ }^{11} \mathrm{C}\right]$ raclopride were observed in normal human subjects (Ito et al., 2008), it has been reported that interindividual difference in $B_{\text {avail }}$ was significant, but not that in $K_{\mathrm{D}}$, in human $\left[{ }^{11} \mathrm{C}\right]$ raclopride PET studies (Farde et al., 1995). This indicates that the interindividual variation of $\mathrm{BP}_{\mathrm{ND}}$ would be mainly due to the interindividual difference in $B_{\text {avail }}$ rather than $K_{\mathrm{D}}$. $B_{\text {avail }}$ is the receptor density available to bind radiotracer in vivo, and it might be smaller than the receptor density in vitro assays due to the competition with endogenous dopamine (Innis et al., 2007). Thus, the interindividual variation of $\mathrm{BP}_{\mathrm{ND}}$ would be due to both the interindividual difference in the receptor density and that in the concentration of endogenous dopamine in the synaptic cleft.

Another possible reason for a significant negative correlation between presynaptic and postsynaptic dopaminergic functions might be a compensative relation between the two functions. The mechanism for the regulation of dopamine release from presynapse has been explained by both phasic and tonic dopamine release (Grace, 1991). Phasic dopamine release would be caused by firing of dopaminergic neuron, and tonic dopamine release would set the background level of dopamine receptor stimulation. If the endogenous dopamine synthesis ability at rest condition measured by L- $\left[\beta^{-11} \mathrm{C}\right]$ DOPA PET can indicate tonic dopamine release, the background level of dopamine receptor stimulation by tonic dopamine release might be compensatively related to the dopamine $\mathrm{D}_{2}$ receptor density, indicating that the tone of dopaminergic neurotransmission might not be so different between subjects. In addition, the TaqIA1 allele of dopamine $\mathrm{D}_{2}$ receptor gene has been reported to be associated with a low density of dopamine $\mathrm{D}_{2}$ receptors (Jönsson et al., 1999) and with increased striatal activity of AADC in healthy human subjects (Laakso et al., 2005), supporting our present results. They attempted to explain these findings by a lower dopamine $\mathrm{D}_{2}$ receptor expression leading to decreased autoreceptor function, and therefore increased dopa-

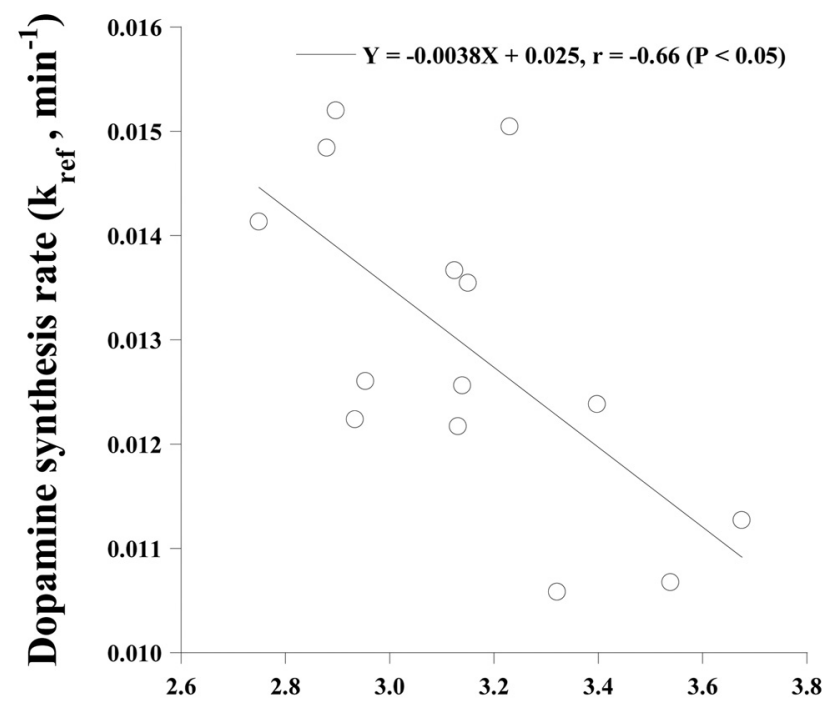

\section{Dopamine $\mathrm{D}_{2}$ receptor binding $\left(\mathrm{BP}_{\mathrm{ND}}\right)$}

Figure 1. Relation between $\mathrm{BP}_{\mathrm{ND}}$ of $\left[{ }^{11} \mathrm{C}\right]$ raclopride studies and $k_{\text {ref }}$ of $\mathrm{L}-\left[\beta{ }^{11} \mathrm{C}\right] \mathrm{DOPA}$ studies in the striatum.

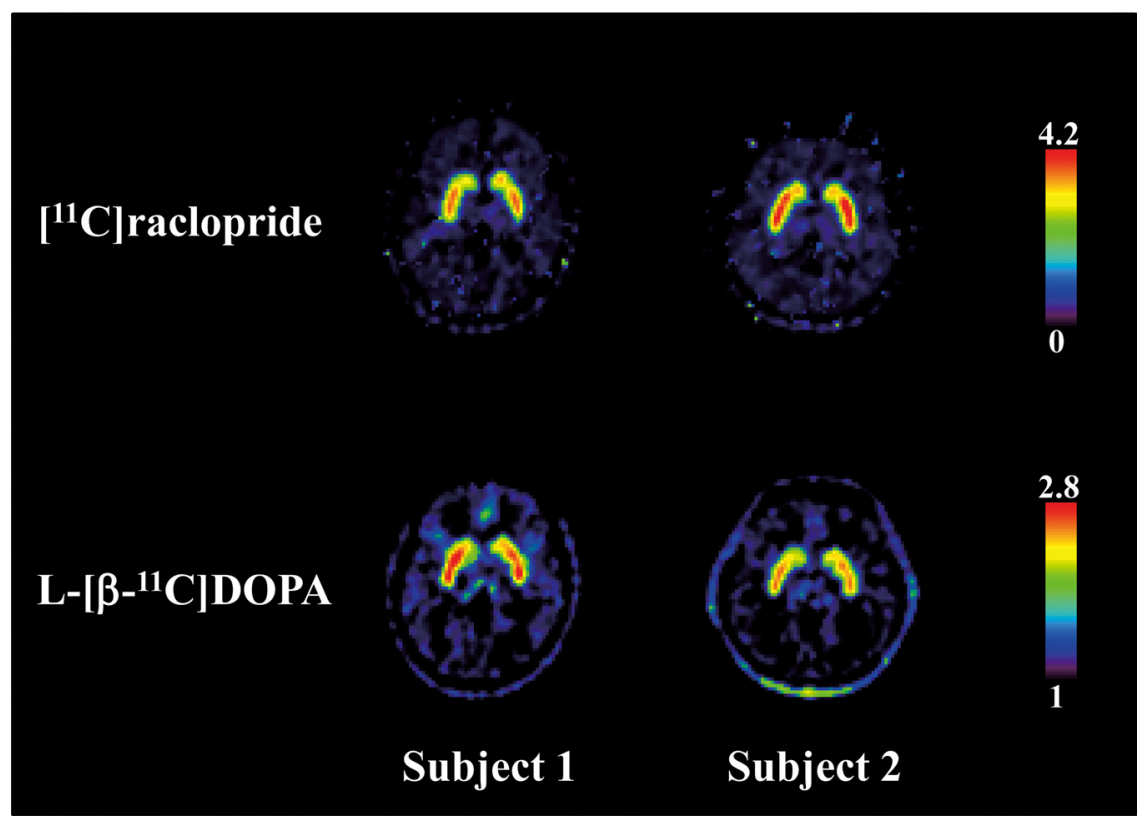

Figure 2. Typical images of $\mathrm{BP}_{\mathrm{ND}}$ of $\left[{ }^{11} \mathrm{C}\right]$ raclopride studies for subjects with low and high $\mathrm{BP}_{\mathrm{ND}}$ (subjects 1 and 2, respectively) and corresponding images indicating dopamine synthesis rate calculated as the ratio of time-integrated radioactivities from 29 to $89 \mathrm{~min}$ of $\mathrm{L}-\left[\beta_{-}{ }^{11} \mathrm{C}\right] \mathrm{DOPA}$ studies between brain regions and the occipital cortex (Ito et al., 2007).

mine synthesis. However, further studies, including animal studies in vitro and in vivo, will be required to explain the negative correlation between presynaptic and postsynaptic dopaminergic functions in the present study.

Increased striatal dopamine synthesis rate in neurolepticnaive or -free patients with schizophrenia has been reported using PET with L- $\left[\beta-{ }^{11} \mathrm{C}\right]$ DOPA (Lindström et al., 1999; Nozaki et al., 2009) or 6- $\left[{ }^{18} \mathrm{~F}\right]$ fluoro-L-DOPA (Hietala et al., 1995). On the other hand, no significant change in striatal dopamine $\mathrm{D}_{2}$ receptor density in patients with schizophrenia has been reported using PET with $\left[{ }^{11} \mathrm{C}\right]$ raclopride (Farde et al., 1990). It might be 
valuable to investigate the relation between presynaptic and postsynaptic dopaminergic functions in patients with schizophrenia whether such compensative relation in the striatum was evident or disrupted in patients.

It has been reported that the dopamine $\mathrm{D}_{2}$ receptor density measured by PET with $\left[{ }^{11} \mathrm{C}\right]$ raclopride was significantly correlated with a certain personality trait, the detachment score of Karolinska Scales of Personality (Farde et al., 1997; Breier et al., 1998), while no significant correlation was observed between the endogenous dopamine synthesis rate measured by PET with 6 - $\left[{ }^{18} \mathrm{~F}\right]$ fluoro-L-DOPA and the detachment score (Laakso et al., 2003). On the other hand, endogenous dopamine synthesis was significantly correlated with anxiety-related personality scales of Karolinska Scales of Personality (Laakso et al., 2003). These findings indicate that dopamine $\mathrm{D}_{2}$ receptor density and the endogenous dopamine synthesis rate might be related to personality traits independently, although a significant negative correlation was observed between parameters for both presynaptic and postsynaptic functions in the present study. The relations between personality traits and presynaptic or postsynaptic dopaminergic functions should be further investigated in large series of subjects.

NAAs are transported by the neutral amino acid carrier system in the blood-brain barrier in a competitive fashion (Oldendorf, 1971; Pardridge, 1977; Ito et al., 1995), and the competitive transport of L-DOPA with NAAs at the blood-brain barrier has been revealed (Ito et al., 2006). We have previously reported a significant negative correlation between the weighted sum of the NAAs and the overall uptake rate constant of $\mathrm{L}-\left[\beta_{-}{ }^{11} \mathrm{C}\right] \mathrm{DOPA}$ calculated using the arterial input function (Ito et al., 2006). The overall uptake rate constant calculated using the arterial input function includes the influx rate constant at the blood-brain barrier, and therefore negatively correlated with the weighted sum of the NAAs due to the competitive transport at the bloodbrain barrier. In the present study, no significant correlation was observed between the weighted sum of NAAs in plasma and the dopamine synthesis rate $k_{\text {ref }}$ of $\mathrm{L}_{-}\left[\beta^{-}{ }^{11} \mathrm{C}\right] \mathrm{DOPA}$. Because $k_{\mathrm{ref}}$ is calculated using time-activity data in a reference brain region, not in arterial plasma, this parameter does not reflect the influx rate constant at the blood-brain barrier (Ito et al., 2006, 2007). Thus, the dopamine synthesis rate $k_{\text {ref }}$ of $\mathrm{L}-\left[\beta-{ }^{11} \mathrm{C}\right] \mathrm{DOPA}$ is independent of the NAA concentration.

In conclusion, a significant negative correlation was observed between parameters for both presynaptic and postsynaptic dopaminergic functions in the striatum of normal human subjects. Although the interindividual variation of $\mathrm{BP}_{\mathrm{ND}}$ would be due to both the interindividual difference in the receptor density and that in the concentration of endogenous dopamine in the synaptic cleft, this relation might indicate a compensative relation between the two functions. Further studies to elucidate the interindividual variation in dopaminergic neurotransmission tone of neuropsychiatric disorders will be required.

\section{References}

Breier A, Kestler L, Adler C, Elman I, Wiesenfeld N, Malhotra A, Pickar D (1998) Dopamine $\mathrm{D}_{2}$ receptor density and personal detachment in healthy subjects. Am J Psychiatry 155:1440-1442.

Brix G, Zaers J, Adam LE, Bellemann ME, Ostertag H, Trojan H, Haberkorn U, Doll J, Oberdorfer F, Lorenz WJ (1997) Performance evaluation of a whole-body PET scanner using the NEMA protocol. J Nucl Med 38:1614-1623.

Brown RM, Crane AM, Goldman PS (1979) Regional distribution of monoamines in the cerebral cortex and subcortical structures of the rhesus monkey: concentrations and in vivo synthesis rates. Brain Res 168: $133-150$.
Farde L, Ehrin E, Eriksson L, Greitz T, Hall H, Hedström CG, Litton JE, Sedvall G (1985) Substituted benzamides as ligands for visualization of dopamine receptor binding in the human brain by positron emission tomography. Proc Natl Acad Sci U S A 82:3863-3867.

Farde L, Halldin C, Stone-Elander S, Sedvall G (1987) PET analysis of human dopamine receptor subtypes using ${ }^{11} \mathrm{C}-\mathrm{SCH} 23390$ and ${ }^{11} \mathrm{C}$ raclopride. Psychopharmacology 92:278-284.

Farde L, Wiesel FA, Stone-Elander S, Halldin C, Nordström AL, Hall H, Sedvall G (1990) $\mathrm{D}_{2}$ dopamine receptors in neuroleptic-naive schizophrenic patients. A positron emission tomography study with $\left[{ }^{11} \mathrm{C}\right]$ raclopride. Arch Gen Psychiatry 47:213-219.

Farde L, Hall H, Pauli S, Halldin C (1995) Variability in $\mathrm{D}_{2}$-dopamine receptor density and affinity: a PET study with $\left[{ }^{11} \mathrm{C}\right]$ raclopride in man. Synapse 20:200-208.

Farde L, Gustavsson JP, Jönsson E (1997) $\mathrm{D}_{2}$ dopamine receptors and personality traits. Nature 385:590.

Friston KJ, Frith CD, Liddle PF, Dolan RJ, Lammertsma AA, Frackowiak RS (1990) The relationship between global and local changes in PET scans. J Cereb Blood Flow Metab 10:458-466.

Gjedde A (1988) Exchange diffusion of large neutral amino acids between blood and brain. In: Peptide and amino acid transport mechanisms in the cerebral nervous system (Rakic L, Begley DJ, Davson H, Zlokovic BV, eds), pp 209-217. New York: Stockton.

Gjedde A, Reith J, Dyve S, Léger G, Guttman M, Diksic M, Evans A, Kuwabara H (1991) Dopa decarboxylase activity of the living human brain. Proc Natl Acad Sci U S A 88:2721-2725.

Grace AA (1991) Phasic versus tonic dopamine release and the modulation of dopamine system responsivity: a hypothesis for the etiology of schizophrenia. Neuroscience 41:1-24.

Halldin C, Stone-Elander S, Farde L, Ehrin E, Fasth KJ, Långström B, Sedvall G (1986) Preparation of ${ }^{11} \mathrm{C}$-labelled SCH 23390 for the in vivo study of dopamine D-1 receptors using positron emission tomography. Int J Rad Appl Instrum A 37:1039-1043.

Hartvig P, Agren H, Reibring L, Tedroff J, Bjurling P, Kihlberg T, Långström B (1991) Brain kinetics of $\mathrm{L}-\left[\beta_{-}{ }^{11} \mathrm{C}\right]$ dopa in humans studied by positron emission tomography. J Neural Transm Gen Sect 86:25-41.

Heinz A, Siessmeier T, Wrase J, Buchholz HG, Gründer G, Kumakura Y, Cumming P, Schreckenberger M, Smolka MN, Rösch F, Mann K, Bartenstein P (2005) Correlation of alcohol craving with striatal dopamine synthesis capacity and $\mathrm{D}_{2 / 3}$ receptor availability: a combined $\left[{ }^{18} \mathrm{~F}\right] \mathrm{DOPA}$ and $\left[{ }^{18} \mathrm{~F}\right] \mathrm{DMFP}$ PET study in detoxified alcoholic patients. Am J Psychiatry 162:1515-1520.

Hietala J, Syvälahti E, Vuorio K, Räkköläinen V, Bergman J, Haaparanta M, Solin O, Kuoppamäki M, Kirvelä O, Ruotsalainen U, Salokangas RKR (1995) Presynaptic dopamine function in striatum of neuroleptic-naive schizophrenic patients. Lancet 346:1130-1131.

Huang SC, Yu DC, Barrio JR, Grafton S, Melega WP, Hoffman JM, Satyamurthy N, Mazziotta JC, Phelps ME (1991) Kinetics and modeling of L-6$\left[{ }^{18} \mathrm{~F}\right]$ fluoro-dopa in human positron emission tomographic studies. J Cereb Blood Flow Metab 11:898-913.

Innis RB, Cunningham VJ, Delforge J, Fujita M, Gjedde A, Gunn RN, Holden J, Houle S, Huang SC, Ichise M, Iida H, Ito H, Kimura Y, Koeppe RA, Knudsen GM, Knuuti J, Lammertsma AA, Laruelle M, Logan J, Maguire RP, et al. (2007) Consensus nomenclature for in vivo imaging of reversibly binding radioligands. J Cereb Blood Flow Metab 27:1533-1539.

Ito H, Hatazawa J, Murakami M, Miura S, Iida H, Bloomfield PM, Kanno I, Fukuda H, Uemura K (1995) Aging effect on neutral amino acid transport at the blood-brain barrier measured with L- $\left[2-{ }^{18} \mathrm{~F}\right]$-fluorophenylalanine and PET. J Nucl Med 36:1232-1237.

Ito H, Hietala J, Blomqvist G, Halldin C, Farde L (1998) Comparison of the transient equilibrium and continuous infusion method for quantitative PET analysis of $\left[{ }^{11} \mathrm{C}\right]$ raclopride binding. J Cereb Blood Flow Metab 18:941-950.

Ito H, Ota M, Ikoma Y, Seki C, Yasuno F, Takano A, Maeda J, Nakao R, Suzuki K, Suhara T (2006) Quantitative analysis of dopamine synthesis in human brain using positron emission tomography with $\mathrm{L}-\left[\beta-{ }^{11} \mathrm{C}\right] \mathrm{DOPA}$. Nucl Med Commun 27:723-731.

Ito H, Shidahara M, Takano H, Takahashi H, Nozaki S, Suhara T (2007) Mapping of central dopamine synthesis in man using positron emission tomography with L- $\left[\beta-{ }^{11} \mathrm{C}\right]$ DOPA. Ann Nucl Med 21:355-360.

Ito H, Takahashi H, Arakawa R, Takano H, Suhara T (2008) Normal data- 
base of dopaminergic neurotransmission system in human brain measured by positron emission tomography. Neuroimage 39:555-565.

Jönsson E, Sedvall G, Brené S, Gustavsson JP, Geijer T, Terenius L, Crocq MA, Lannfelt L, Tylec A, Sokoloff P, Schwartz JC, Wiesel FA (1996) Dopamine-related genes and their relationships to monoamine metabolites in CSF. Biol Psychiatry 40:1032-1043.

Jönsson EG, Nöthen MM, Grünhage F, Farde L, Nakashima Y, Propping P, Sedvall GC (1999) Polymorphisms in the dopamine $\mathrm{D}_{2}$ receptor gene and their relationships to striatal dopamine receptor density of healthy volunteers. Mol Psychiatry 4:290-296.

Kienast T, Siessmeier T, Wrase J, Braus DF, Smolka MN, Buchholz HG, Rapp M, Schreckenberger M, Rösch F, Cumming P, Gruender G, Mann K, Bartenstein P, Heinz A (2008) Ratio of dopamine synthesis capacity to $D_{2}$ receptor availability in ventral striatum correlates with central processing of affective stimuli. Eur J Nucl Med Mol Imaging 35:1147-1158.

Köhler C, Hall H, Ogren SO, Gawell L (1985) Specific in vitro and in vivo binding of ${ }^{3} \mathrm{H}$-raclopride. A potent substituted benzamide drug with high affinity for dopamine D-2 receptors in the rat brain. Biochem Pharmacol 34:2251-2259.

Laakso A, Wallius E, Kajander J, Bergman J, Eskola O, Solin O, Ilonen T, Salokangas RK, Syvälahti E, Hietala J (2003) Personality traits and striatal dopamine synthesis capacity in healthy subjects. Am J Psychiatry 160:904-910.

Laakso A, Pohjalainen T, Bergman J, Kajander J, Haaparanta M, Solin O, Syvälahti E, Hietala J (2005) The Al allele of the human $\mathrm{D}_{2}$ dopamine receptor gene is associated with increased activity of striatal L-amino acid decarboxylase in healthy subjects. Pharmacogenet Genomics 15:387-391.

Lammertsma AA, Hume SP (1996) Simplified reference tissue model for PET receptor studies. Neuroimage 4:153-158.

Lammertsma AA, Bench CJ, Hume SP, Osman S, Gunn K, Brooks DJ, Frackowiak RS (1996) Comparison of methods for analysis of clinical $\left[{ }^{11} \mathrm{C}\right]$ raclopride studies. J Cereb Blood Flow Metab 16:42-52.

Lindström LH, Gefvert O, Hagberg G, Lundberg T, Bergström M, Hartvig P, Långström B (1999) Increased dopamine synthesis rate in medial prefrontal cortex and striatum in schizophrenia indicated by $\mathrm{L}-\left(\beta-{ }^{11} \mathrm{C}\right)$ DOPA and PET. Biol Psychiatry 46:681-688.

Lloyd KG, Hornykiewicz O (1972) Occurrence and distribution of aromatic
L-amino acid (L-DOPA) decarboxylase in the human brain. J Neurochem 19:1549-1559.

Nagatsu T (1991) Genes for human catecholamine-synthesizing enzymes. Neurosci Res 12:315-345.

Nozaki S, Kato M, Takano H, Ito H, Takahashi H, Arakawa R, Okumura M, Fujimura Y, Matsumoto R, Ota M, Takano A, Otsuka A, Yasuno F, Okubo Y, Kashima H, Suhara T (2009) Regional dopamine synthesis in patients with schizophrenia using L- $\left[\beta-{ }^{11}\right.$ C]DOPA PET. Schizophr Res 108: $78-84$.

Okada M, Nakao R, Hosoi R, Zhang MR, Fukumura T, Suzuki K, Inoue O (2011) Microdialysis with radiometric monitoring of $\mathrm{L}-\left[\beta_{-}{ }^{11} \mathrm{C}\right] \mathrm{DOPA}$ to assess dopaminergic metabolism: effect of inhibitors of $\mathrm{L}$-amino acid decarboxylase, monoamine oxidase, and catechol-O-methyltransferase on rat striatal dialysate. J Cereb Blood Flow Metab 31:124-131.

Oldendorf WH (1971) Brain uptake of radiolabeled amino acids, amines, and hexoses after arterial injection. Am J Physiol 221:1629-1639.

Pardridge WM (1977) Kinetics of competitive inhibition of neutral amino acid transport across the blood-brain barrier. J Neurochem 28:103-108.

Patlak CS, Blasberg RG (1985) Graphical evaluation of blood-to-brain transfer constants from multiple-time uptake data. Generalizations. J Cereb Blood Flow Metab 5:584-590.

Reeves SJ, Mehta MA, Montgomery AJ, Amiras D, Egerton A, Howard RJ, Grasby PM (2007) Striatal dopamine $\left(\mathrm{D}_{2}\right)$ receptor availability predicts socially desirable responding. Neuroimage 34:1782-1789.

Sugaya Y, Sasaki Y, Goshima Y, Kitahama K, Kusakabe T, Miyamae T, Kato T, Misu Y (2001) Autoradiographic studies using L- $\left[{ }^{14} \mathrm{C}\right] \mathrm{DOPA}$ and L-DOPA reveal regional $\mathrm{Na}^{+}$-dependent uptake of the neurotransmitter candidate L-DOPA in the CNS. Neuroscience 104:1-14.

Tedroff J, Aquilonius SM, Hartvig P, Lundqvist H, Bjurling P, Långström B (1992) Estimation of regional cerebral utilization of $\left[{ }^{11} \mathrm{C}\right]-\mathrm{L}-3,4-$ dihydroxyphenylalanine (DOPA) in the primate by positron emission tomography. Acta Neurol Scand 85:166-173.

Watson CC, Newport D, Casey ME (1996) A single scatter simulation technique for scatter correction in 3D PET. In: Three-dimensional image reconstruction in radiology and nuclear medicine (Grangeat P, Amans JL, eds), pp 255-268. Dordrecht, The Netherlands: Kluwer Academic. 